\title{
PERANCANGAN ULANG BODY KIT PREAMPLIFIER GITAR BASS ELEKTRIK MENGGUNAKAN METODE NIGEL CROSS
}

Edi Suprayitno', Mochammad Chaeron², Muhammad Shodiq Abdul Khannan²

1. Alumni Jurusan Teknik Industri

2. Jurusan Teknik Industri

Jurusan Teknik Industri Fakultas Teknik Industri

Universitas Pembangunan Nasional Veteran Yogyakarta

Jl. Babarsari No. 2 Tambakbayan, Yogykarta 55281

email : shodiq@upnyk.ac.id

\begin{abstract}
ABSTRAK
Seiring perkembangan industri musik di Indonesia yang semakin maju persaingan dalam bermain musik semakin ketat. Dalam bermain musik banyak membutuhkan alat pembantu demi terciptanya suara yang merdu, selain itu juga untuk menunjang kreatifitas para musisi dalam menciptakan sebuah karya. Alat pembantu dalam bermusik bermacam-macam, salah satunya adalah alat preamplifier gitar bass elektrik. Preamplifier ini di pasaran harganya sangatlah mahal, yang belum tentu terjangkau oleh para musisi, selain itu cara penggunaanya juga terlalu rumit bagi para musisi pemula, dan dirasa cukup berat bobot dari alat preamp ini.

Melihat permasalahan di atas maka perlunya dilakukan perancangan ulang alat preamplifier gitar bass elektrik ini dengan melakukan wawancara langsung kepada pengguna preamp yang notabenenya pernah memakai alat preamplifier gitar bass elektrik ini saat bermusik. Maka diharapkan alat preamplifier gitar bass elektrik hasil rancangan nanti akan sesuai dengan keinginan dan kebutuhan konsumen. Kemudian dilakukan perancangan alat menggunakan pendekatan model design Nigel Cross. Pengembangan desain ini diawali dengan mengklasifikasikan tujuan-tujuan dari perancangan dan menetapkan fungsi serta batasan sistem. Setelah itu menyusun kebutuhan konsumen untuk membuat spesifikasi alat pengaman yang baru, kemudian menetapkan karakteristik yang bertujuan untuk menentukan target apa yang akan dicapai sehingga sesuai kebutuhan konsumen. Selanjutnya pembangkitan alternatif dari alat preamplifier gitar bass elektrik desain baru, kemudian akan dievaluasi untuk dipilih yang mana yang terbaik.

Berdasarkan hasil penelitian yang dilakukan terbukti bahwa alat preamplifier gitar bass elektrik hasil rancangan ulang memiliki spesifikasi sebagai berikut, yaitu dari segi ukuran tidak memakan tempat, ringan, lebih memudahkan bagi pengguna dalam pengoprasianya dan harganya yang terjangkau. Sedangkan dari beberapa kombinasi alternatif, terdapat 3 alternatif yang terpilih dari perolehan hasil terbanyak dan alternatif 1 merupakan pilihan terbaik. Maka biaya pembelian bahan lebih murah dibandingkan pilihan alternatif yang lain. Setelah spesifikasi sudah sesuai dengan keinginan konsumen selanjutnya alat preamplifier gitar bass elektrik diuji coba, dan hasil uji coba dapat berjalan dengan baik sesuai tujuan yang diinginkan.
\end{abstract}

Kata Kunci: Preamplifier gitar bass elektrik, Nigel cross, pengoperasian mudah, harga terjangkau.

\section{PENDAHULUAN}

Seiring perkembangan industri musik di Indonesia yang semakin maju persaingan dalam bermain musik semakin ketat, banyak hal yang dapat mendukung agar terciptanya alunan musik yang bagus seperti peralatan bermusik gitar, sound, mic, efek dan lain-lain. Oleh sebab itu para pelaku industri musik harus dapat bersaing tidak hanya dari segi seni individu saja namun juga harus memiliki peralatan musik yang bagus terutama pada grup musik yang menggunakan berbagai macam alat musik.

Penggunaan alat musik dan alat pendukung lain dalam bermusik bertujuan untuk membantu dalam berkreasi membuat sebuah nada dan musik yang merdu. Salah satu dari alat pendukung lain dalam bermusik yaitu preamplifier gitar bass elektrik. Alat preamplifier adalah sebuah alat pendukung untuk mengeluarkan dan menguatkan daya signal yang dikeluarkan oleh input signal atau dalam bahasa yang sederhana adalah sebagai penguat sinyal audio yang masih lemah. Preamplifier biasa disebut juga dengan efek gitar. Alat pendukung bermusik ini perannya tidak bisa digantikan atau bahkan dihilangkan, oleh karena itu semua pelaku di industri musik harus memilikinya. Preamp yang digunakan untuk kalangan pemusik pro saat ini dari segi tampilan sangatlah susah untuk digunakan para gitaris pemula bahkan yang sudah professional. Dari 20 pengguna alat preamplifier yang sudah ada, $70 \%$ diantaranya sekitar 14 orang mengeluhkan terdapat 12 macam knob yang butuh kejelian untuk mengatur semua itu. Selain itu $100 \%$ dari 20 pengguna mengeluhkan susahnya pengoperasian alat tersebut. Maka 
dari itu, perlu dikembangkannya alat preamp bass dengan tampilan sederhana (knob tidak terlalu banyak tapi cukup dan sangat berguna, ukuran tulisan knob pada box mudah di lihat dari jarak pandang satu sampai tiga meter, tampilan menarik dan bahan yang dipakai kuat tapi tidak berat, dan memiliki karakter suara yang lebih luas), serta sangat mudah di operasikan baik dari pemusik pemula maupun yang sudah profesional. Sehingga pengguna bisa lebih mengembangkan dan mendapatkan karakter suara yang di inginkan sesuai dengan karakter alat musik bass yang dipakai. Selain itu diharapkan dengan perancangan ulang ini nantinya akan mendapatkan nilai jual yang terjangkau dipasaran dengan menggunakan bodykit yang sama kualitasnya dengan yang ada di pasaran saat ini. Preamplifier yang ada di pasaran mempunyai banyak tombol dan dengan beberapa fungsi yang sama, bentuk body kit yang rumit terkadang membuat susah dalam mengoprasikan untuk pemain bass.

Dari uraian di atas terlihat adanya kebutuhan alat preamplifier gitar bass yang mempunyai body kit lebih mudah untuk di oprasikan, seperti tombol-tombol yang lebih mudah di mengerti cara penggunaannya, harganya yang terjangkau serta kekuatan atau ketahanan alat. Perancangan ulang body kit alat preamplifier gitar bass ini akan dikaji dengan menggunakan metode Nigel Cross sesuai dengan kebutuhan konsumen. Metode Nigel Cross merupakan metode aternatif selain Quality Function Deployment (Khannan, 2010) dan metode Pahl\&Beitz (Dharma, dkk., 2018).

\section{LANDASAN TEORI}

\subsection{Ergonomi}

Produk merupakan salah satu unsur yang paling penting dalam sebuah pasar, karena dengan adanya produk maka akan terjadi pertukaran dan transaksi jual beli antara produsen dan konsumen. Untuk itu, dalam menghasilkan produk dari sebuah perusahaan hendaknya perusahaan harus mengerti apa kebutuhan serta keinginan para konsumen agar nantinya dapat sesuai dengan kebutuhan serta keinginan konsumen. Produk yang sesuai dengan keinginan serta kebutuhan konsumen nantinya akan dapat diterima oleh konsumen dengan baik (Sutalaksana dan Iftikar, 2006)

2.2 Perancangan dan Pengembangan Produk

Banyak perusahaan yang menghadapi sebuah masalah, mereka dituntut untuk harus berinovasi dalam menciptakan sebuah produk yang baru, teteapi kemungkinan sukses sangat kecil. Secara keseluruhan, untuk menciptakan produk yang baru dan di terima di pasaran, perusahaan harus memeahami karakteristik dari para konsumennya, pasar, dan pesaing serta dapat memberikan nilai lebih yang unggul bagi para pelanggan. Perusahaan harus memiliki rencana yang matang untuk menghasilkan produk baru yang kuat dan mempersiapkan proses pengembangan produk secara sistematis untuk menemukan dan mengembangkan produk-produk baru.

2.2.1 Tahap-tahap dalam merancang dan mengembangkan produk

Menurut Cross (1989), dalam melakukan perancangan produk diperlukan proses-proses perancangan seperti terlihat pada Gambar 2.1.

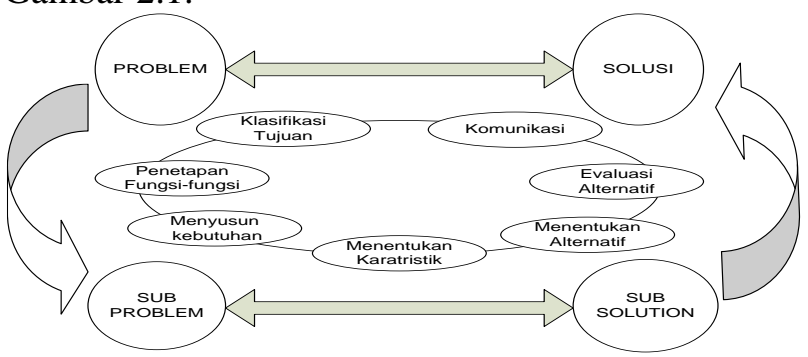

Gambar 2.1 Langkah-langkah perancangan produk (Sumber: Cross dalam Ferry, 2016)

Langkah-langkah perancangan produk menurut Nigel Cross ada sebanyak tujuh langkah yang mempunyai yang masing-masing mempunyai metode tersendiri yaitu:

\section{Klarifikasi Tujuan}

Langkah pertama yang penting dalam merancang adalah berupaya untuk memperjelas tujuan perancangan. Pada kenyataannya, sangat membantu dalam hasil di tiap langkah hingga hasil yang diharapkan. Akhir dari klarifikasi tujuan ini adalah sekumpulan tujuan perancangan objek yang harus dibuat walaupun tujuan-tujuan yang dibuat itu mungkin saja berubah dalam proses perancangan berikutnya.

Metode pohon tujuan memberikan bentuk dan penjelasan dari pernyataan tujuan. Metode ini menunjukkan tujuan dan sasaran yang akan dicapai dengan berbagai pertimbangan. Prosedur pembuatan pohon tujuan ini adalah :

a. Membuat daftar tujuan perancangan

b. Susun daftar dalam urutan tujuan dari higher-level kepada lower-level. 
c. Gambarkan sebuah diagram pohon tujuan, untuk menunjukkan hubunganhubungan yang hierarki.

2. Penetapan Fungsi

Dari metode pohon tujuan, dapat dilihat maksud dari permasalahan yang ada mempunyai banyak tingkatan-tingkatan perbedaan yang umum maupun secara rinci. Dengan nyata, tingkat setiap permasalahan memberi arti sangat penting bagi atau oleh perancang. Langkah selanjutnya adalah menetapkan fungsi. Tujuannya adalah untuk menetapkan fungsi-fungsi yang diperlukan dan batas-batas sistem rancangan produk yang baru. Pada langkah ini digunakan metode analisis fungsional.

Metode analisis fungsional menawarkan seperti mempertimbangkan fungsi esensial alat, hasil atau produk atau sistem yang dirancang harus memuaskan, tidak masalah komponen fisik apa yang seharusnya digunakan. Tingkat permasalahan diputuskan dengan mendirikan pembatas di sektor peletakan pengganti yang saling berkaitan dari fungsi.

3. Menyusun Kebutuhan

Setelah fungsi ditetapkan, makalangkah selanjutnya adalah menyusun kebutuhan. Langkah ketiga ini bertujuan untuk membuat spesifikasi pembuatan yang akurat yang perlu bagi desain/ rancangan.

Metode yang digunakan pada langkah ini adalah Performance Specification Model, yang prosedur pelaksanaannya adalah :

a. Mempertimbangkan tingkatantingkatan solusi yang berbeda yang dapat diaplikasikan.

b. Menentukan tingkatan untuk beroperasi.

c. Identifikasi atribut-atribut performansi yang diinginkan.

d. Menentukan kebutuhan performansi untuk setiap atribut.

4. Menetapkan Karakteristik

Selanjutnya adalah langkah yang disebut penentuan karakteristik, yang bertujuan untuk menetukan target apa yang akan dicapai oleh karakteristik teknik suatu produk sehingga dapat memuaskan kebutuhan-kebutuhan konsumen.

5. Pembangkitan Alternatif

Tujuan dari langkah ini adalah dihasilkannya solusi-solusi rancangan alternatif. Metode yang digunakan adalah metode Morphological Chart. Metode ini mendorong perancang-perancang untuk mengidentifikasi atau mencari kombinasi elemen-elemen yang baru. Tujuan dari metode ini adalah untuk memperluas pencarian bagi solusi-solusi baru yang mungkin. Prosedur pelaksanaan metode Morfologi Chart adalah:

a. Buat daftar hal-hal penting atau fungsifungsi yang penting untuk produksi. Daftar jangan terlalu panjang, dan harus secara luas mencakup fungsifungsinya.

b. Untuk tiap hal atau fungsi, buat daftar cara-cara yang dapat dicapai oleh tiap fungsi. Daftar ini dapat mencakup ideide baru yang dikenal baik sebagai komponen-komponen atau sub-sub solusi yang sudah ada.

c. Gambarkan sebuah peta yang berisi semua sub-sub solusi yang mungkin.

d. Identifikasi kombinasi sub-sub solusi yang dapat dijalankan.

6. Evaluasi Alternatif

Alternatif-alternatif yang sudah dihasilkan kemudian akan dievaluasi untuk dipilih mana yang menjadi terbaik. Pada langkah ini, digunakan metode Weighted Objective yang bertujuan untuk membandingkan nilai-nilai bantu dari setiap proposal berdasarkan kemungkinan bobot tujuan yang berbeda-beda.

Prosedur pelaksanaan metode ini adalah :

a. Daftarkan tujuan perancangan.

b. Golongkan urutan daftar tujuan.

c. Berikan Hubungan kepentingan pada tujuan.

d. Menetapkan parameter pelaksanaan atau nilai kegunaan untuk masingmasing tujuan.

e. Hitung dan bandingkan hubungan nilai kegunaan perancangan alternatif.

7. Rincian Perbaikan

Banyak pekerjaan perancangan dalam praktek tidak dikaitkan dengan kreasi atas konsep perancangan baru yang radikal, tetapi pembuatan modifikasi untuk mewujudkan rancangan sebuah produk. Modifikasi ini berusaha mengembangkan suatu produk, meningkatkan penampilannya, mengurangi berat, menurunkan biaya, dan mempertinggi daya tariknya. Semua bentuk modifikasi biasanya dapat dibagi ke dalam dua tipe, yaitu modifikasi yang bertujuan meningkatkan nilai produk untuk pembeli dan mengurangi biaya bagi produsen. 
Langkah pengembangan rancangan ini menggunakan metode teknik nilai. Metode teknik nilai ini bertujuan untuk meningkatkan atau mempertahankan nilai produk bagi pembeli dan mengurangi biaya bagi produsen.

Prosedur pelaksanaan metode ini adalah :

a. Membuat daftar komponen suatu produk dan mengidentifikasi fungsi dari tiap komponen.

b. Menentukan nilai dari fungsi yang diidentifikasi. Nilai inilah yang diperhatikan oleh pelanggan.

c. Menentukan biaya komponen, setelah diselesaikan dan dipasang.

d. Mencari cara mengurangi biaya tanpa menurunkan nilai, atau menambah nilai tanpa memperbesar biaya.

Mengevaluasi alternatif dan memilih pengembangan.

\section{METODOLOGI PENELITIAN \\ 3.1 Objek Penelitian}

Penelitian dilakukan pada pengguna gitar bass elektrik di daerah Yogyakarta dan sekitarnya. Data yang dikaji adalah keluhan pengguna gitar bass elektrik pemula yang kesulitan untuk mengoprasikan preamplifier gitar bass sebagai alat penunjang dalam bermusik, dikarenakan rumitnya body kit dan banyak tombol untuk mengoprasikan.

\subsection{Pengumpulan Data}

Metode pengumpulan data untuk mendapatkan informasi dalam menyusun laporan ini data yang diperoleh berupa:

\section{Data primer}

Data yang diperoleh secara langsung dari objek yang diteliti, data ini diperoleh dengan metode wawancara yaitu:

a. Data keunggulan preamplifier yang beredar di pasaran yang telah digunakan oleh pengguna gitar bass elektrik di Yogyakarta dan sekitarnya.

b. Data penggunaan preamplifier gitar bass yang sering digunakan.

c. Keluhan terhadap preamplifier yang digunakan komunitas gitar bass elektrik di Yogyakarta dan sekitarnya.

\section{Data sekunder}

Data yang diperoleh secara tidak langsung dari sumbernya, data ini dapat diambil dari literaturliteratur, publikasi dan internet.

\subsection{Langkah-langkah Perancangan Nigel Cross}

Langkah-langkah perancangan alat adalah sebagai berikut:

1. Kuesioner

Kuesioner atau angket adalah pernyataan tertulis yang digunakan untuk memperoleh informasi dari beberapa responden dalam arti laporan tentang pendapat pribadi atau hal-hal yang ia ketahui tentang produk yang sedang diteliti yaitu preamplifier gitar bass elektrik. Dalam tahapan ini akan dilakukan 4 kegiatan lanjutan, yaitu:

\section{a) Uji kecukupan data}

Uji kecukupan data pada penelitian kali ini adalah untuk menentukan jumlah sample data yang akan diambil untuk dilakukan proses pengolahan data selanjutnya.

b) Uji keseragaman data

Uji keseragaman data ini digunakan untuk melihat apakah data yang diperoleh dari penyebaran kuesioner dilapangan masih dalam batas kontrol (batas kontrol atas dan batas kontrol bawah).

c) Uji validasi

Uji validasi ini dilakukan untuk menguji kemampuan kuesioner yang akan di sebarkan sehingga benar-benar dapat mengukur hasil yang diperoleh dari penyebaran kuesioner yang kan dilakukan.

d) Uji reliabilitas

Uji reliabilitas dilakukan untuk mengukur sejauh mana hasil dari data yang diperoleh itu dapat dipercaya.

2. Identifikasi Costumer need atau Kuesioner Identifikasi Costumer need atau kuesioner adalah pengamatan dan pencarian informasi tentang permasalahan dan kebutuhan para konsumen untuk menggunakan alat preamplifier dengan melakukan penyebaran kuesioner tertutup.

3. Klarifikasi tujuan

Tahap yang pertama adalah mengklasifikasikan tujuan yang ingin dicapai dalam merancang alat preamplifier yang berisikan tentang kebutuhan konsumen atau pengguna gitar bass listrik.

4. Penetapan fungsi

Pada tahap penetapan fungsi ini dimulai dengan menyusun fungsi sistem dari alat preamplifier dengan model black box, selanjutnya dilakukan analisis fungsi-fungsi yang diperlukan dan batasan-batasan sistem rancangan alat preamplifier.

5. Menyusun kebutuhan

Dalam tahap ini mengidentifikasi dan menentukan kebutuhan performansi untuk 
setiap atribut-atribut yang diperlukan pada saat penyusunan atribut alat preamplifier.

6. Penentuan karakteritik

Dalam tahap ini dilakukan dengan cara mengidentifikasi keinginan konsumen/pengguna gitar bass listrik kedalam atribut-atribut produk, menentukan tingkat kepentingan relatif dari atribut-atribut, membuat matrik perlawanan antara atribut produk dengan karakteristik produk, selanjutnya mengidentifikasi hubungan antara karakteristik teknis dan tahap akhir yaitu menentukan gambaran target yang ingin dicapai untuk karakteristik perancangan alat preamplifier.

7. Pembangkitan alternatif

Pembangkitan alternatif dilakukan dengan pertimbangan beberapa alternatif bahan yang akan digunakan untuk pembuatan alat preamplifier gitar bass dan digunkan sebagi solusi pembuatan preamplifier.

8. Evaluasi alternatif

Dalam hal ini yang dilakukan adalah perancangan secara detail dengan menggambar komponen yang diperlukan kedalam Bill of Material (BOM), pembuatan peta proses operasi, gambar komponen yang akan dipakai.

9. Analisis biaya pengembangan

Analisis biaya pengembangan berkaitan dengan biaya yang dikeluarkan untuk melakukan produksi dan pengembangan preamplifier dengan menggunakan Persamaan 2.8 untuk melakukan perhitungan harga pokok produksi.

\subsection{Analisis Hasil}

\section{Analisis Biaya}

Pada tahap ini akan dilakukan perhitungan biaya secara rinci yaitu yang mencakup:

a) Biaya komponen dari alat preamplifier baik itu biaya pembelian maupun biaya pembuatan komponen

b) Biaya perakitan komponen preamplifier.

c) Menentukan harga pokok penjualan dari alat preamplifier sehingga siap dipasarkan.

\section{Analisis Kepuasan}

Pada tahap ini peneliti ingin mendapatkan respon yang baik terhadap alat preamplifier yang dirancang, berdasarkan dari kuesioner yang diberikan kepada responden pemain gitar bass elektrik di wilayah Yogyakarta dan sekitarnya.

\subsection{Kesimpulan dan saran}

Setelah perancangan berhasil maka tahap akhir adalah membuat kesimpulan mengenai perancangan body kit preamplifier dan saran yang bertujuan untuk referensi penelitian selanjutnya

\section{HASIL DAN PEMBAHASAN}

Dari hasil wawancara yang dilakukan kepada para gitaris pemula di lapangan sebanyak 20 responden yang berada di kabupaten Sleman, didapatkan kesimpulan bahwa produk preamp saat ini yang beredar $\mathrm{d}$ ipasaran dirasa masih sangat susah pengoperasianya khususnya bagi para gitaris pemula, serta harganya yang relatif tidak dapat dijangkau oleh para gitaris pemula.

a) Uji kecukupan data

Setelah dilakukan penyebaran kuesioner sebanyak 20 responden. Berdasarkan dari hasil kuesioner, digunakan untuk mencari uji kecukupan data dengan persamaan sebagai berikut :

$$
N^{\prime}=\left[\frac{\frac{k}{s} \sqrt{N \cdot \sum X_{i}^{2}-\left(\sum X_{i}\right)^{2}}}{\sum X_{i}}\right]^{2}
$$

Sehingga,

$$
N^{\prime}=\left[\frac{\frac{2}{0,05} \sqrt{20.10670-(460)^{2}}}{460}\right]^{2}
$$

$\mathrm{N}^{\prime}=[3,7]^{2}=13,6$

Dari hasil perhitungan di atas, nilai N' adalah 13,6 atau lebih kecil daripada $N$. Maka dapat dinyatakan bahwa data sudah cukup untuk dijadikan sampel.

b) Uji keseragaman data

Dari hasil rekapitulasi data kuesioner di diuji keseragaman data dan hasil pengujian menunjukkan data bersifat seragam.

c) Hasil uji validasi kuesioner

Dari hasil uji validasi menggunakan software SPSS 16.0 dari data 6 butir pertanyaan pada kuesioner A.1 dinyatakan valid, karena memiliki nilai $r$ hitung lebih besar daripada $r$ tabel. Untuk lebih jelasnya dapat dilihat hasil uji validitas pada Tabel 4.2.

\begin{tabular}{|c|c|c|}
\hline $\mathrm{r}_{\text {tabel }}=$ & ,443 & \\
\hline Atribut & $\begin{array}{l}\text { Corrected Item } \\
\mathrm{r}_{\text {hitung }}\end{array}$ & Keterangan \\
\hline 1 & 0,682 & Valid \\
\hline
\end{tabular}

Tabel 4.2 Hasil uji validasi 


\begin{tabular}{|l|l|l|}
2 & 0,542 & Valid \\
\hline 3 & 0,616 & Valid \\
\hline 4 & 0,508 & Valid \\
\hline 5 & 0,594 & Valid \\
\hline 6 & 0,730 & Valid \\
\hline
\end{tabular}

d) Hasil uji reliabilitas kuesioner Pengujian dengan menggunakan software SPSS menunjukan data reliabel karena dari hasil perhitungan menunjukan nilai alpha Cronbach lebih dari 0,6. Untuk lebih jelasnya hasil uji reliabilitas dapat dilihat pada Tabel 4.3.

Tabel 4.3 Hasil uji reliabilitas

\begin{tabular}{|l|r|l|}
\hline Atribut & $\mathrm{A}_{\text {tetapan }}=0,6$ & Keterangan \\
\hline $\begin{array}{l}\text { Cronbach's } \\
\text { Alpha }\end{array}$ & 0,645 & Reliabel \\
\hline
\end{tabular}

\subsection{Identifikasi Kebutuhan Konsumen}

Tahap awal dalam perancangan produk yakni dengan mengidentifikasi kebutuhan dan keinginan konsumen. Adapun data-data yang digunakan adalah sebagai berikut:

1. Survei pendahuluan

Pada tahap awal sebelum dilakukan penyebaran kuesioner, terlebih dahulu dilakukan survei pendahuluan kepada beberapa pengguna preamplifier gitar bass, mengenai bentuk alat preamplifier, ukuran alat, kemudahan pengoprasian alat, kualitas alat, dan bobot dari alat preamplifier, serta keluhan yang dirasakan selama menggunakan alat preamplifier yang beredar dipasaran saat ini. Hal ini dilakukan bertujuan untuk mempermudah dalam pembuatan spesifikasi alat yang diinginkan oleh pengguna preamplifier gitar bass elektrik dalam hal kenyamanan dalam penggunaanya. Adapun beberapa keluhan-keluhan yang dirasakan dapat dilihat pada Tabel 4.4

Tabel 4.4 Keluhan-keluhan pengguna preamplifier gitar bass elektrik

\begin{tabular}{|l|l|}
\hline \multicolumn{1}{|c|}{$\begin{array}{c}\text { Voice } \\
\text { of Costumer }\end{array}$} & \multicolumn{1}{c|}{ Costumer Needs } \\
\hline $\begin{array}{l}\text { Bentuk alat } \\
\text { yang kurang } \\
\text { menarik }\end{array}$ & $\begin{array}{l}\text { Bentuk alat yang simple } \\
\text { dan menarik }\end{array}$ \\
\hline $\begin{array}{l}\text { Ukuran alat } \\
\text { yang kecil }\end{array}$ & Ukuran alat yang sedang \\
\hline $\begin{array}{l}\text { Pengoprasian } \\
\text { alat sangat } \\
\text { rumit yang }\end{array}$ & $\begin{array}{l}\text { Pengoperasian } \\
\text { mudah dan sederhana }\end{array}$ \\
\hline
\end{tabular}

\begin{tabular}{|lr|l|}
$\mid$\begin{tabular}{|l}
$|2|$ \\
Kualitas bahan \\
yang mudah \\
pecah
\end{tabular} & Kualitas bahan yang kuat \\
\hline $\begin{array}{l}\text { Bobot alat } \\
\text { yang relatif } \\
\text { berat }\end{array}$ & Bobot alat yang ringan \\
\hline $\begin{array}{l}\text { Harga alat } \\
\text { yang mahal }\end{array}$ & Harga alat yang murah \\
\hline
\end{tabular}

2. Hasil kuesioner

Dalam tahap ini ada dua jenis kuesioner yang akan diberikan kepada 20 responden pengguna preamplifier gitar bass elektrik, yaitu:

A. Kuesioner terbuka

Diberikan kepada 20 responden pengguna preamplifier, kemudian dari kuesioner pendahuluan sebelumnya dapat diketahui mengenai ukuran perangkat yang diinginkan serta keluhan-keluhan pada alat keamanan yang sudah ada sebelumnya. Kuesioner terbuka ini dilakukan untuk mengetahui informasi atribut kebutuhan dan keinginan pengguna preamplifier mengenai kemudahan pengoprasian alat serta terjangkaunya harga dari alat preamplifier. Adapun atribut kebutuhan dan keinginan pengguna sepeda motor dapat dilihat pada Tabel 4.5.

Tabel 4.5. Atribut kebutuhan dan keinginan pengguna preamplifier

\begin{tabular}{|l|l|}
\hline No & \multicolumn{2}{|c|}{ Atribut Kebutuhan } \\
\hline 1 & $\begin{array}{l}\text { Box menggunakan bahan plat } \\
\text { aluminium }\end{array}$ \\
\hline 2 & $\begin{array}{l}\text { Pengoprasian knop mudah dengan cara } \\
\text { diputar }\end{array}$ \\
\hline 3 & $\begin{array}{l}\text { Penggunaan switch mudah dengan cara } \\
\text { ditekan }\end{array}$ \\
\hline 4 & Box yang tidak mudah pecah \\
\hline 5 & $\begin{array}{l}\text { Ukuran box perangkat kecil atau } \\
\text { minimalis }\end{array}$ \\
\hline 6 & $\begin{array}{l}\text { Jumlah knob yang sesuai dengan } \\
\text { kebutuhan }\end{array}$ \\
\hline
\end{tabular}

B. Kuesioner tertutup

Setelah hasil kuesioner terbuka (survei pendahuluan) kemudian dilakukan tahap kuesioner tertutup. Hasil kuesioner tertutup dapat dilihat di lampiran A.5, kuesioner tertutup tersebut dilakukan pembobotan untuk mendapatkan tingkat kepentingan kebutuhan dan keinginan pengguna gitar bass elektrik terhadap preamplifier gitar bass elektrik dengan desain yang baru. 


\subsection{Detail Hasil Perancangan}

Detail hasil perancangan adalah suatu upaya untuk memperjelas mengenai bentuk konkrit alat, yaitu menggambarkan semua komponen yang dipakai baik yang dibuat maupun dibeli. Dalam perancangan detail memerlukan data-data antara lain:

1. Data komponen yang harus dibuat dan dibeli

2. Gambar dari seluruh part produk secara detail

3. Proses perancangan preamplifier gitar bass elektrik.

Berdasarkan hasil evaluasi pemilihan alternatif yang didapat, bahwa alternatif 1 adalah pilihan terbaik menurut konsumen. Maka desain alat terdahulu mengalami beberapa perubahan, antar lain pada tombol kontrol dan tata letak posisi kontrol ukuran alat, bobot alat, serta kemudahan pengoperasian alat preamplifier gitar bass elektrik. Berikut gambar preamplifier yang ada di pasaran.
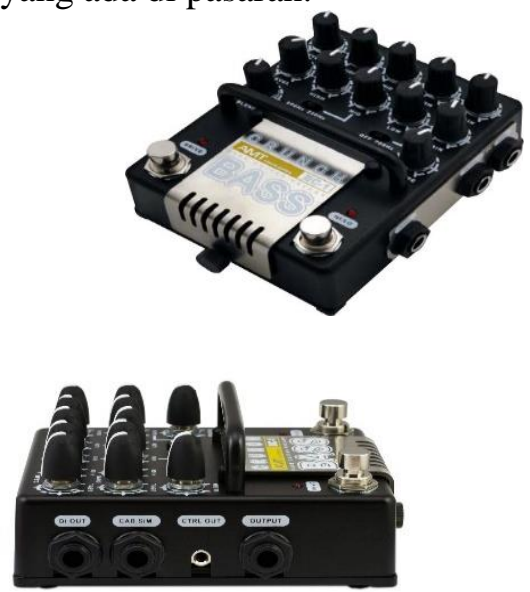

Gambar 4.1 Body kit preamplifier gitar bass elektrik yang ada di pasaran

Setelah melalui beberapa tahapan perancangan alat dan perubahan komponen, bahwa body kit preamplifier dioperasikan dari susunan knob tidak terlalu banyak tapi cukup dan sangat berguna bagi penggunanya, ukuran tulisan pada knob mudah di lihat dari jarak pandang satu sampai tiga meter, tampilan lebih menarik dan bahan yang dipakai kuat akan tetapi memiliki bobot yang cukup ringan, dan memiliki karakter suara yang lebih luas serta lebih bagus. Gambar hasil rancangan perangkat preamplifier gitar bass elektrik dengan desain baru dapat dilihat pada Gambar 4.2.

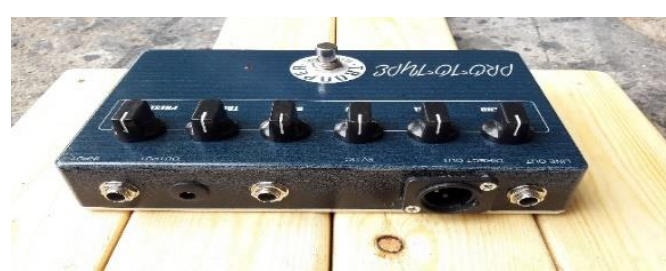

Gambar 4.2 Body kit preamplifier gitar bass elektrik hasil rancangan

\subsection{Rekayasa Nilai (Value Enginering)}

Dalam suatu rancangan tidaklah selalu mudah dalam menentukan biaya yang sebenarnya. Metode akuntansi dalam suatu rancangan mungkin tidak cukup untuk menentukan biaya dari setiap item produk yang sudah teridentifikasi. Oleh karena itu dapat digunakan metode biaya perbaikan agar dapat memberikan informasi yang relevan secara detail mengenai biaya yang mungkin digunakan dalam membuat sebuah produk baru dengan desain baru. Langkah-langkah dalam metode analisis biaya antara lain:

Daftar komponen dan identifikasi fungsi produk

Daftar komponen penting dalam preamplifier gitar bass elektrik secara detail yang digunakan untuk mengatur nada efek yang dikeluarkan oleh gitar bass sehingga menciptakan sebuah suara yang merdu dapat dilihat pada Tabel 4.6

Tabel 4.6 Part produk yang digunakan pada preampliifer gitar bass

\begin{tabular}{|l|l|}
\multicolumn{3}{l}{ preampliifer gitar bass } \\
\hline Komponen & Fungsi \\
\hline BOX & $\begin{array}{l}\text { Sebagai wadah komponen agar } \\
\text { tidak mudah rusak }\end{array}$ \\
\hline Knop & $\begin{array}{l}\text { Alat memudahkan untuk memutar } \\
\text { potensio }\end{array}$ \\
\hline Switch & $\begin{array}{l}\text { Untuk menghubungkan dan } \\
\text { memutuskan arus rangkaian }\end{array}$ \\
\hline $\begin{array}{l}\text { Soket } \\
\text { fleksibel }\end{array}$ & $\begin{array}{l}\text { untuk menghubungkan peralatan } \\
\text { lain }\end{array}$ \\
\hline PCB & dudukan komponen \\
\hline Potensio & $\begin{array}{l}\text { Untuk mengatur nilai resistansi } \\
\text { yang bisa diatur secara variatif }\end{array}$ \\
\hline IC & \multicolumn{2}{|l|}{ Untuk menguatkan signal } \\
\hline $\begin{array}{l}\text { Power } \\
\text { injeksi }\end{array}$ & $\begin{array}{l}\text { Penghubung aliran antar } \\
\text { preamplifier ke stock listrik. }\end{array}$ \\
\hline
\end{tabular}

Harga pada setiap komponen produk

Pada tahapan ini dilakukan pemilihan komponen yang akan digunakan beserta harga 
dari setiap komponen penyusun preamplifier gitar bass elektrik yang telah diperoleh berdasarkan survei langsung di pasar untuk mendapatkan nilai harga yang ada. Harga dari setiap komponen dapat dilihat pada Tabel 4.7

Tabel 4.7 Harga komponen-komponen yang digunakan

\begin{tabular}{|c|c|c|c|c|}
\hline Jenis biaya & Komponen & Harga ( Rp) & jumlah (unit) & jumlah (Rp) \\
\hline \multirow{12}{*}{ biaya tetap } & $B O X$ & 115.000 & 1 & 115.000 \\
\hline & Knop & 9.000 & 6 & 54.000 \\
\hline & Switch & 50.000 & 1 & 50.000 \\
\hline & Soket phono & 7.000 & 3 & 21.000 \\
\hline & Soket $X L r$ & 8.000 & 1 & 8.000 \\
\hline & PCB preamp & 60.000 & 1 & 60.000 \\
\hline & PCB Simulator & 25.000 & 1 & 25.000 \\
\hline & Potensio & 9.000 & 6 & 54.000 \\
\hline & Resistor & 250 & 42 & 10.500 \\
\hline & Kapasitor & 700 & 33 & 23.100 \\
\hline & $I C 1$ & 35.000 & 2 & 70.000 \\
\hline & $I C 2$ & 20.000 & 2 & 40.000 \\
\hline biaya tenaga kerja & & & & 200.000 \\
\hline Overhead & listrik & 20.000 & & 20.000 \\
\hline Total & & & & 750.600 \\
\hline
\end{tabular}

Dari hasil evaluasi dan survei di lapangan yang dilakukan dapat disimpulkan bahwa biaya tetap yang digunakan dalam pembuatan produk ini adalah sebesar Rp.750.000 termasuk biaya perakitan/biaya tenaga kerja sebesar Rp.200.000, yang telah mencakup biaya bahan yang akan dibuat, biaya pekerja perakitan dan biaya pembelian semua komponen penyusun. Jadi total biaya yang harus dikeluarkan oleh perancang dalam pembuatan produk ini yaitu sebesar Rp.750.600 (biaya pokok produksi).

Setelah harga pokok penjualan telah didapatkan dari perhitungan diatas, selanjutnya dari pihak perancang menginginkan keuntungan yang akan didapatkan dari produk yang dibuat yaitu sebesar $10 \%$ dengan rincian sebagai berikut:

Harga jual $=($ Biaya pokok produksi $)$ $+(10 \%$ laba $\mathrm{x}$ Biaya pokok produksi)

$$
\begin{aligned}
& =(750.600)+(10 \% \times 750.600) \\
& =\text { Rp.750.600 }+ \text { Rp.75.060 } \\
& =\text { Rp. 825.660 } \approx \text { Rp. 830.000 }
\end{aligned}
$$

Jadi harga jual produk dengan desain yang baru adalah Rp. 830.000

$\begin{array}{rrr}4.6 & \text { Survei analisis kepuasan } \\ \text { konsumen } & & \end{array}$

Untuk mengetahui apakah alat yang telah dibuat memenuhi kriteria dari konsumen atau tidak, maka perlu dilakukan survei kepuasan konsumen. Untuk mempermudah proses survei terhadap kepuasan konsumen maka dilakukan dengan tanya jawab secara langsung. Suatu rancangan alat bisa dikatakan berhasil dan diterima dipasaran apabila jumlah responden yang diberi kesemptan untuk mencoba secara langsung alat preamplifier gitar bass elektrik yang sudah dirancang ulang merasa puas lebih banyak dibanding jumlah responden yang tidak puas. Dari survei yang dilakukan sebanyak 18 konsumen menjawab puas terhadap alat, 2 konsumen tidak puas. Sedangkan untuk mengetahui respon minat konsumen untuk membeli alat preamplifier gitar bass elektrik dengan desain baru dilakukan penyebaran kuesioner kepada 20 responden, dan hasil yang didapat adalah 16 konsumen berminat untuk membeli, dan 4 konsumen yang tidak berminat untuk membeli alat preamplifier gitar bass elektrik dengan desain baru.

Dari survei yang dilakukan dapat diketahui bahwa lebih banyak responden yang memilih untuk membeli produk preamplifier gitar bass elektrik desain ulang. Terdapat 16 
responden tertarik untuk membelinya dengan alasan dengan harga yang ditawarkan sangat murah. Serta terdapat 18 responden juga merasa lebih sesuai antara keinginannya dengan rancangan desain baru preamplifier gitar bass yang mudah dioperasikan. Kesimpulanya preamplifier gitar bass elektrik diterima oleh konsumen sebagai alternatif alat efek gitar bass elektrik yang bisa membantu dalam bermusik. Hasil kesesuaian rancangan alat dengan keinginan responden dapat dilihat pada Gambar 4.3.

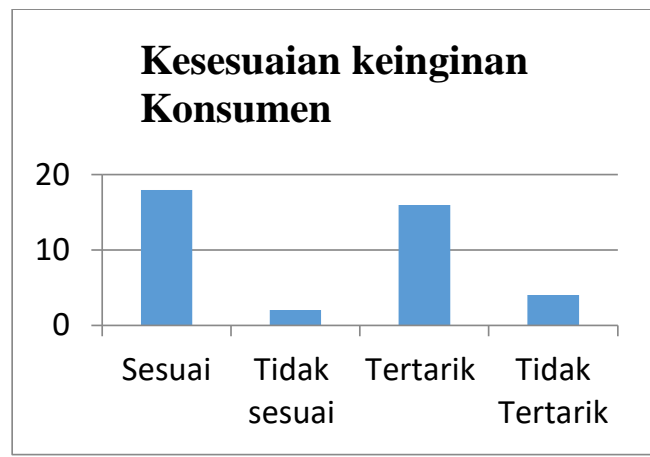

Gambar 4.3 Grafik data responden

Selain dilakukan survei tentang kepuasan konsumen terhadap alat yang telah dibuat, perlu juga dilakukan penilaian secara objective hasil alat yang telah dibuat dari pakar musik yang sudah memiliki pengalaman serta sertifikasi dalam hal penilaian instrumen pendukung dalam bermusik. Hal tersebut dimaksudkan agar nantinya alat tersebut benarbenar layak untuk digunakan oleh masyarakat. Dalam hal ini penilaian dilakukan oleh Bapak Sasi Kirono yang berprofesi sebagai sound enginer, music director, arranger dan sekaligus sebagai player melakukan pengujian hasil suara yang dihasilkan oleh alat sebelum dan sesudah dilakukan perancangan ulang dengan cara dimainkan langsung. Berikut adalah beberapa penilaian yang diberikan secara objective dari Bapak Sasi Kirono.

1. Alat dengan rancangan baru lebih mudah digunakan bagi pemusik pemula.

2. Desain alat yang simple tidak rumit.

3. Jumlah knop yang lebih ringkas dibandingkan dengan jumlah knob dari alat sebelumnya.

4. Bobot alat cukup ringan sehingga lebih nyaman saat dibawa kemana saja.

5. Penggunaan daya yang jauh lebih rendah sehingga mengurangi beban daya diesel sebagai penyuplai energi listrik saat melakukan show outdor.

Selain penilaian secara lisan, beliau juga melakukan pengujian dengan menggunakan software audio. Dapat dilihat dari performansi alat dari software audio dapat dilihat pada Gambar 4.4 dan 4.5.

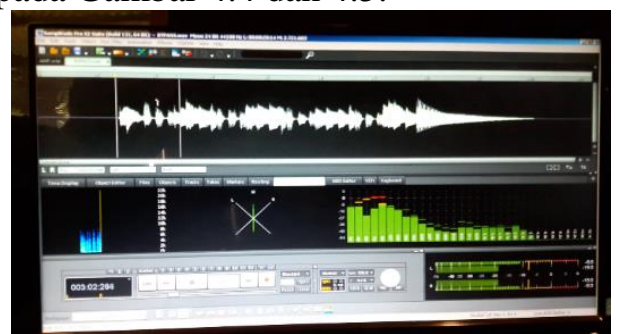

Gambar 4.4 Performansi Alat Rancangan Baru

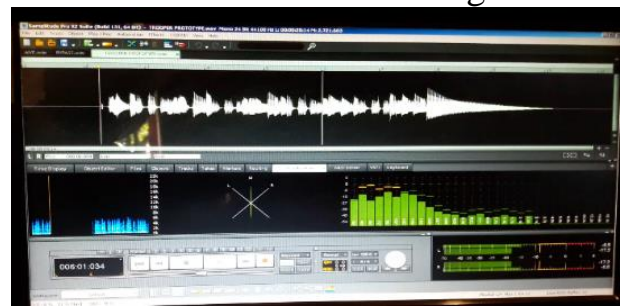

Gambar 4.5 Performansi Alat yang Sudah Ada

Dari gambar yang dilihat diatas dapat dilihat bahwa performansi suara yang dihasilkan dari produk dengan rancangan baru jauh lebih kuat dan stabil daripada dengan performansi alat yang sebelumnya.

\subsubsection{Analisis Hasil}

Dari pengolahan data maka dapat kita analisis kesesuain perancangan desain baru preamplifier gitar bass elektrik, dari 20 responden 15 diantarnya tertarik dan 18 merasa sesuai dengan apa yang diinginkan yaitu preamplifier gitar bass yang mudah dioperasikan dan mudah untuk dipahami bagi pemula, kesesuian dari hasil perancangan ini membuat kepuasan untuk para konsumen. Dengan desain baru preamplifier lebih mudah dioprasikan, knob yang tidak terlalu banyak tapi cukup dan sangat berguna, ukuran tulisan pada knob mudah di lihat dari jarak pandang satu sampai tiga meter, tampilan menarik dan bahan yang dipakai kuat tapi tidak berat, dan memiliki karakter suara yang lebih luas. Selain itu juga alat ini telah di uji oleh orang yang berkompeten dalam hal instrumen musik, yang mana hasil suara yang di hasilkan dari alat preamplifier gitar bass elektrik ini lebih kuat dan stabil dari alat yang sebelumnya. Harga produk pun jauh lebih murah dan sangat terjangkau apabila akan diproduksi massal, dengan harga Rp.830.000. Harga preamplifier gitar bass dengan desain yang baru tersebut 
sangatlah murah dibandingkan dengan yang sudah ada di pasaran saat ini yang mempunyai selisih hampir Rp.4.000.000 dengan kulitas standar yang ditawarkan di pasaran. Harga yang terjangkau dan desain body kit serta oprasional yang mudah membuat alat preamplifier dengan desain yang baru ini akan mudah diterima oleh kalangan pemusik yang baru mau belajar. Dalam pembuatanya preamplifier menggunakan bahan yang kuat dan relatif terjangkau, dari alternatif - alternatif yang diusulkan, alternatif 1 yang mejadi pokok dasar bahan pembuatan alat preamplifier denga menggunkan bahan plat alumunium dan beberpa tombol oprasional yang sesuai seperti switch tekan, knop putar dan beberpa tombol operasional yang lain untuk kemudahan bagi para pemusik dalam menggunakan alat preamplifier gitar bass elektrik ini.

Berikut analisis hasil pengujian secara menyeluruh mengenai perbandingan antara alat preamplifier gitar bass elektrik antara alat preamplifier gitar bass elektrik dengan desain yang lama dan alat preamplifier gitar bass elektrik dengan desain yang baru, hasil perancangan dapat dilihat pada Tabel 4.8.

Tabel 4.8 Perbandingan alat preamplifier gitar bass elektrik desain lama dan desain yang baru

\begin{tabular}{|c|c|c|}
\hline Kriteria & $\begin{array}{l}\text { Preamplifier } \\
\text { Desain Baru }\end{array}$ & $\begin{array}{l}\text { Preamplifier } \\
\text { Dengan Desain } \\
\text { Lama }\end{array}$ \\
\hline Bobot Alat & $\begin{array}{l}\text { Terasa cukup } \\
\text { ringan } \\
\text { sehingga } \\
\text { mudah dan } \\
\text { ringan ketika } \\
\text { dibawa pada } \\
\text { saat menuju } \\
\text { lokasi show }\end{array}$ & $\begin{array}{l}\text { Terasa cukup } \\
\text { berat sehingga } \\
\text { pengguna } \\
\text { merasa kurang } \\
\text { nyaman ketika } \\
\text { membawa alat } \\
\text { ini ke lokasi } \\
\text { show }\end{array}$ \\
\hline $\begin{array}{l}\text { Ketahanan } \\
\text { Alat }\end{array}$ & $\begin{array}{l}\text { Lebih kuat } \\
\text { dan lebih } \\
\text { tahan } \\
\text { terhadap } \\
\text { guncangan } \\
\text { daripada alat } \\
\text { baru }\end{array}$ & $\begin{array}{l}\text { Mudah terjadi } \\
\text { troubel ketika } \\
\text { alat terkena } \\
\text { goncangan } \\
\text { maupun } \\
\text { benturan }\end{array}$ \\
\hline Desain & $\begin{array}{l}\text { Lebih simple } \\
\text { dan ringkas } \\
\text { karena tidak } \\
\text { memakai } \\
\text { banyak } \\
\text { tombol serta } \\
\text { jarak antar }\end{array}$ & $\begin{array}{l}\text { Desain terlalu } \\
\text { rumit karena } \\
\text { memakai } \\
\text { banyak tombol } \\
\text { serta jarak } \\
\text { tombol yang } \\
\text { begitu dekat }\end{array}$ \\
\hline
\end{tabular}

\begin{tabular}{|c|c|c|}
\hline & $\begin{array}{l}\text { tombol tidak } \\
\text { terlalu } \\
\text { berdekatan }\end{array}$ & \\
\hline $\begin{array}{l}\text { Pengoperasi } \\
\text { an }\end{array}$ & $\begin{array}{l}\text { Pengoperasia } \\
\mathrm{n} \text { alat cukup } \\
\text { mudah dan } \\
\text { ringkas bagi } \\
\text { pengguna } \\
\text { pemusik } \\
\text { pemula, } \\
\text { mudah } \\
\text { digunakan } \\
\text { meskipun } \\
\text { instrumen } \\
\text { pembantu } \\
\text { musik lainya } \\
\text { tidak lengkap }\end{array}$ & $\begin{array}{l}\text { Pengoperasian } \\
\text { alat yang } \\
\text { cukup rumit } \\
\text { bagi para } \\
\text { pemusik } \\
\text { pemula, serta } \\
\text { dibutuhkan } \\
\text { instrumen } \\
\text { pembantu } \\
\text { yang lengkap } \\
\text { dalam } \\
\text { pengoprasiany } \\
\text { a }\end{array}$ \\
\hline $\begin{array}{l}\text { Kebutuhan } \\
\text { Daya }\end{array}$ & $\begin{array}{l}\text { Kebutuhan } \\
\text { daya yang } \\
\text { relatif lebih } \\
\text { rendah } \\
\text { sehingga } \\
\text { lebih } \\
\text { menghemat } \\
\text { kebutuhan } \\
\text { listrik }\end{array}$ & $\begin{array}{l}\text { Kebutuhan } \\
\text { daya yang } \\
\text { cukup besar } \\
\text { sehingga } \\
\text { membebankan } \\
\text { dalam } \\
\text { konsumsi } \\
\text { listrik }\end{array}$ \\
\hline Harga & $\begin{array}{l}\text { Jauh lebih } \\
\text { terjangkau } \\
\text { daripada } \\
\text { harga alat } \\
\text { preamplifier } \\
\text { yang ada di } \\
\text { pasaran saat } \\
\text { ini. }\end{array}$ & $\begin{array}{l}\text { harga cukup } \\
\text { mahal } \\
\text { sehingga } \\
\text { jarang para } \\
\text { pemusik } \\
\text { pemula yang } \\
\text { dapat membeli } \\
\text { alat ini }\end{array}$ \\
\hline $\begin{array}{l}\text { Karakter } \\
\text { Suara }\end{array}$ & $\begin{array}{l}\text { Karakter } \\
\text { suara yang } \\
\text { dihasilkan } \\
\text { sangat luas }\end{array}$ & $\begin{array}{l}\text { Karakter suara } \\
\text { yang } \\
\text { dihasilkan } \\
\text { kurang luas }\end{array}$ \\
\hline
\end{tabular}

\section{KESIMPULAN}

Berdasarkan pengolahan data analisa hasil penelitian disimpulkan yaitu :

1. Berdasarkan hasil penelitian, maka dapat disimpulkan bahwa alat preamplifier gitar bass elektrik dengan desain baru telah teruji dan dapat bekerja dengan baik sesuai dengan keinginan dan kebutuhan konsumen.

2. Ditinjau dari aspek harga yang ditawarkan jauh lebih murah dengan preamplifier gitar bass elektrik yang beredar sebelumnya. Setelah dilakukan perancangan ulang alat preamplifier gitar bass elektrik dengan desain baru, 
maka biaya yang harus dikeluarkan dalam pembuatanya sebesar Rp. 830.000 rupiah. Selisih biaya yang jauh lebih murah dari sebelumnya yaitu kisaran Rp 4.000.000 rupiah setelah dirancang ulang menjadi $\mathrm{Rp} 830.000$ rupiah, pengguna preamplifier gitar bass elektrik sudah mendapatkan fungsi alat yang sama dengan preamplifier gitar bass elektrik sebelumnya.

3. Hasil penyebaran kuesioner kepada 20 responden yang didapat, bahwa 90\% responden merasa nyaman dan puas dengan menggunakan preamplifier gitar bass elektrik dengan desain yang baru, lebih mudah atau praktis dalam penggunaanya.

4. Alat hasil rancangan memiliki performansi yang lebih stabil dan kuat dalam menghasilkan suara, hal ini di buktikan dari hasil software pengujian kualitas preamp dan dengan dimainkan langsung oleh seorang yang telah mempunyai lisensi untuk melakukan pengujian instrument musik

\section{DAFTAR PUSTAKA}

Cross, N., 1989, Engineering Design Methods: Strategies for Product Design, Second Edition, John Wiley \& Sons, New York

Dharma, G.O., Lucitasari, D.R., dan Khannan, M.S.A., 2018, Perancangan Ulang Headset dan Penutup Mata Untuk Tidur Menggunakan Metode Nigel Cross, Jurnal OPSI Vol 11 No.1 Juni 2018 hal 65-77.

Ferry, H., 2016, Perancangan Alat Pengaman Pada Kendaraan Bermotor, Tugas Akhir, UPN "Veteran", Yogyakarta.

Ginting, R., 2010, Perancangan Produk, Graha Ilmu, Cetakan Pertama, Yogyakarta.

Khannan, M.S.A., 2010, The application of quality function deployment to increase powder detergent quality, Proceeding 3rd International Seminar on Industrial Engineering and Management (3rd ISIEM), eprints.upnyk.ac.id

Sutalaksana \& Iftikar, Z., 2006. Teknik Perancangan Sistem Kerja. ITB. Bandung

Ulrich, K. T., dan Eppinger, S. D., 2001, Perancangan Dan Pengembangan Produk, Salemba Teknik, Jakarta 